\title{
Combining phosphorus (P) with phosphate solubilizing bacteria (PSB) improved wheat yield and $P$ uptake in alkaline soil
}

\author{
Akif Hussain ${ }^{1}$, Muhammad Adnan ${ }^{*}$, Hajira ${ }^{2}$, Sadia Iqbal ${ }^{3}$, Shah Fahad ${ }^{1}$, \\ Muhammad Saeed ${ }^{1}$, Ishaq Ahmad Mian², Mamoona Wali Muhammad ${ }^{4}$, \\ Muhammad Romman ${ }^{5}$, Rainaz Perveez ${ }^{6}$, Fazli Wahid ${ }^{1}$, Fazli Subhan ${ }^{1}$, \\ Mian Ahmad Raza ${ }^{1}$, Muhammad Zamin ${ }^{1}$, Fazl Ullah ${ }^{1}$, Khalil ur \\ Rehman $^{7}$ and Shahla Andaleeb ${ }^{7}$ \\ 1. Department of Agriculture, University of Swabi-Pakistan \\ 2. Department of Soil and Environmental Sciences, University of Agriculture Peshawar-Pakistan \\ 3. Department of Agriculture Chemistry University of Agriculture Peshawar-Pakistan \\ 4. Forest Education Division, Pakistan Forest Institute PFI Peshawar-Pakistan \\ 5. Department of Botany, University of Chitral-Pakistan \\ 6. Department of Botany, Government Degree Collage, Dargai-Pakistan \\ 7. Department of Environmental Sciences, GC Women University, Sialkot-Pakistan \\ *Corresponding author's email: madnanses@gmail.com
}

Citation

Akif Hussain, Muhammad Adnan, Hajira, Sadia Iqbal, Shah Fahad, Muhammad Saeed, Ishaq Ahmad Mian, Mamoona Wali Muhammad, Muhammad Romman, Rainaz Perveez, Fazli Wahid, Fazli Subhan, Mian Ahmad Raza, Muhammad Zamin, Fazl Ullah, Khalil ur Rehman and Shahla Andaleeb. Combining phosphorus (P) with phosphate solubilizing bacteria (PSB) improved wheat yield and P uptake in alkaline soil. Pure and Applied Biology. Vol. 8, Issue 2, pp1809-1817. http://dx.doi.org/10.19045/bspab.2019.80124

\begin{tabular}{llll}
\hline \hline Received: 02/04/2019 & Revised: 20/06/2019 & Accepted: 24/06/2019 & Online First: 28/06/2019 \\
\hline \hline
\end{tabular}

\section{Abstract}

Phosphate solubilizing bacteria can reduce dependence on chemical phosphorus $(\mathrm{P})$ fertilizers by mineralizing and solubilizing indigenous soil P. What's why, we assessed the interactive effect of phosphate solubilizing bacteria (with and without PSB) and phosphorus levels (60, 90 and $120 \mathrm{~kg} \mathrm{P}_{2} \mathrm{O}_{5} \mathrm{ha}^{-}$ ${ }^{1}$ ) on $\mathrm{P}$ uptake and yield of wheat crop under field conditions. Two factorial randomized complete block design (RCBD) with three replications was used. The PSB inoculation significantly enhanced plant height (3\%), 1000 grains weight (12\%), grain (6\%), biological (13\%) and straw yield (18.5\%) of wheat over control. Inoculation with PSB also significantly improved plant $\mathrm{P}$ concentration and uptake (26\% each) over un-inoculated control. Similarly, with increasing application rates of $\mathrm{P}$ from 60 to $120 \mathrm{~kg} \mathrm{P}_{2} \mathrm{O}_{5} \mathrm{ha}^{-1}$ the tested parameter were significantly improved except straw yield. The interactive effect of PSB and P exhibited significant effect on 1000 grains weight while the rest of parameter didn't respond significantly. However, generally PSB inoculation with P enhanced yield attributes and improved P use efficiency over sole application of P. Thus it may be concluded that PSB should be applied with P to enhance wheat yield and $\mathrm{P}$ use efficiency.

Keywords: Alkaline soils; PSB inoculation; Phosphorus uptake; Wheat 


\section{Introduction}

Wheat (Triticum aestivum L.) is a major cereal crop of Pakistan and used as a staple food [1]. It is estimated that by 2020 wheat demand in developing countries is going to increase by $1.6 \%$ per annum [2]. Thus improving wheat yield is very crucial for maintaining global food security. According to Food and Agriculture Organization (FAO) projection, food productivity should be increased about by $70 \%$ in-between 2005 2050 [3, 4]. Adaptation of modern technologies, using good seeds, fertilizers and irrigation could be possible ways for achieving the target to ensure food security [5].

Phosphorus (P) ranks $2^{\text {nd }}$ in term of its requirement by plant and plays vital role in root development, cell division, flower, seeds and fruit formation [6]. Pakistani soils are naturally poor in $\mathrm{P}$ due to high $\mathrm{pH}$ and lime contents which leads to the limitation of crop growth. The biologically available $\mathrm{P}$ exist in soil are primary and secondary orthophosphate. Crop yield can be improved by optimum application of $\mathrm{P}$ as chemical fertilizers [7]. However, only $10-30 \%$ of the applied $\mathrm{P}$ is used by the plant while the rest lost in soil in many ways [8].

Phosphate solubilizing microorganisms (PSM) can be explored for their potential to enhance $\mathrm{P}$ availability and the crop yields [9, 10]. As they can play vital role for in enhancing plant growth under $\mathrm{P}$ deficient soils [11]. They are Phosphate economical, echo friendly to expensive chemical $\mathrm{P}$ fertilizers. PSM's inoculation enhance $P$ availability and the crop yields by solubilizing the soil fixed and applied P [12]. Species of the genus Aspergillus, Bacillus, Pseudomonas, Penicilliumare and Rhizobium are the potential $\mathrm{P}$ solubilzers commonly present in alkaline soil [13]. They may produce the low molecular weight organic acids, lowering of $\mathrm{pH}$ in the surroundings and solubilize the insoluble phosphates. Organic acids may also act as chelating agents by discharging their functional groups thus, chelate the cations bonded to $\mathrm{P}$ thus, solubilize the insoluble phosphates [14]. In addition to organic acid release, the enzyme phosphatase released by PSM has a significant role in solubilization of insoluble P [15]. Siderophores, chelating compounds and mineral acids produced by PSMs and PSB has also been reported responsible for increasing P solubilization [16]. That's why, the present attempt was made to appraise the effect of PSB in enhancing $P$ availably form phosphatic fertilizers applied at different rates on wheat crop with the following objectives.

\section{Materials and methods Experimental site}

A field experiment was conducted at the agronomic research farm of the department of Agriculture university of Swabi. The aim of this study was to evaluate the associative effect of PSB and Phosphatic fertilizer on yield and $P$ uptake in wheat crop. The soil of experimental site was silt loamy, alkaline and calcareous and deficient in organic matter, nitrogen and phosphorus (Table 1).

Table 1. Characteristics of experimental site

\begin{tabular}{|c|c|c|}
\hline Property & Units & Values \\
\hline Textural Class & - & Silt loam \\
\hline Organic matter & $\%$ & 0.92 \\
\hline Lime Content & $\%$ & 14.33 \\
\hline $\mathrm{pH}$ & - & 7.9 \\
\hline EC & $\mathrm{d} \mathrm{Sm}^{-1}$ & 0.72 \\
\hline Total nitrogen & $\%$ & 0.04 \\
\hline Phosphorous & $\mathrm{mg} \mathrm{kg}^{-1}$ & 3.89 \\
\hline
\end{tabular}




\section{Treatment combination}

This attempt was made to explore the interactive role of $\mathrm{P}$ rates and PSB inoculation on $\mathrm{P}$ uptake and growth of wheat at the agronomic research farm, University of Swabi. This project was executed using factorial RCB design in triplicates. There were two factors including two types of inoculation (with PSB and without PSB) and three levels of $\mathrm{P}\left(60,90\right.$ and $120 \mathrm{~kg} \mathrm{P}_{2} \mathrm{O}_{5}$ ha $^{-}$ $\left.{ }^{1}\right)$ making a total of 6 treatment each replicated three times.

\section{Experimental procedure}

The inoculums of PSB inoculum composed of Mycobacterium, Pseudomonas, Rhizobia, Burkholderia, Pantoea and Bacillus were obtained from Department of Microbiology, Hazara University, Mansehra. The seed of wheat verity Serin was inoculated with PSB as per proposed treatment via using stander inoculation procedure. The plots were treated with 60,90 and $120 \mathrm{Kg} \mathrm{P}_{2} \mathrm{O}_{5} \mathrm{ha}^{-1}$ according to the treatment using SSP fertilizer as a source. Inoculated and un-inoculated wheat seed were sown at the rate of $120 \mathrm{Kg} \mathrm{ha}^{-1}$ in $30 \mathrm{~cm}$ apart rows while keeping a plant to plant $15 \mathrm{~cm}$ in a plot of size $3 \times 5 \mathrm{~m}^{2}$. Uniform dosage of $\mathrm{N}$ and $\mathrm{K}_{2} \mathrm{O}$ was applied @ 120 and $60 \mathrm{Kg} \mathrm{ha}{ }^{-1}$ through urea and sulphate of Potash (SOP) fertilizers. Normal recommended cultural practices were adopted during the growth period. Data were recorded throughout the growing season under field conditions.

\section{Agronomic parameter}

Plant height $(\mathrm{cm})$ was measured as mean of five randomly selecting plants from each experimental unit at the peak of physiological maturity from base to the tip of spike. The plants from central two rows were harvested, sun dried threshed and weighed in each treatment plot and the yield was converted into $\mathrm{kg} \mathrm{ha}^{-1}$. Thousand grains were randomly counted from the harvest of each treatment plot and their weight was measured by sensitive electronic balance. The plants from central two rows were harvested and sun dried in each treatment plot and was weighed as such for P TDM yield. The yield was then converted into $\mathrm{kg} \mathrm{ha}^{-1}$. Straw yield of each treatment plot was measured by subtracting grain yield from biological yield (TMD) of each respective plot and was converted into $\mathrm{kg} \mathrm{ha}^{-1}$.

\section{Plant analysis}

The wheat plant samples obtained from each experimental plot at harvest was processed for $\mathrm{P}$ concentration and uptake. A $0.5 \mathrm{~g}$ oven dried plant sample was taken into $150 \mathrm{ml}$ flask and treated with $10 \mathrm{ml}$ concentrated nitric acid for $24 \mathrm{hrs}$. Then, $4 \mathrm{ml} \mathrm{HClO}_{4}$ was added followed by gentle heating till the emergence of white fumes for obtaining $3 \mathrm{ml}$ of the colorless aliquot. The aliquot was then transferred to $100 \mathrm{ml}$ volumetric flask and $\mathrm{P}$ was determined by spectrophotometer by using stander procedure of Richards [17]. The total P uptake by wheat was taken as a product of total $\mathrm{P}$ and total dry matter yield.

\section{Statistical analysis}

The replicated data collected on each parameter was subjected to analysis of variance (ANOVA) of two factor complete randomized block design according to the procedure of Steel and Torrie [18]. In case of significant results the data were further subjected to least significant difference (LSD) test at 5\% level of probability for obtaining variations among treatments for various parameters.

\section{Results and discussion Plant height}

Result for the effect of P, PSB and their interaction present in (Table 2). Upon analysis of various result demonstrated that $P$ rates and PSB inoculation significantly affected plant height while their interactive effect was non-significant. It was exhibited by the result that PSB inoculation improved wheat plant height over un inoculated treatment. Application of $\mathrm{P}$ at the rate of 120 $\mathrm{kg} \mathrm{P}_{2} \mathrm{O}_{5} \mathrm{ha}^{-1}$ produced taller plants $(93 \mathrm{~cm})$, 
which was considerably taller than that of 90 $\mathrm{kg} \mathrm{ha}^{-1}$ where the lowest plant height was recorded at $60 \mathrm{~kg} \mathrm{ha}^{-1}$. These result demonstrated that PSB inoculation along with $\mathrm{P}$ fertilization can further enhance the plant height of wheat and thus can pertain to increased production. Our results are in agreement to [19] who reported that $\mathrm{P}$ applied at the rate of $90 \mathrm{~kg} \mathrm{P}_{2} \mathrm{O}_{5}$ ha $^{-1}$ had significantly increased plant height $(93.63 \mathrm{~cm})$.

Table 2. Response of wheat plant height $(\mathrm{cm})$ to $P$ application rates and PSB inoculation

\begin{tabular}{|c|c|c|c|}
\hline \multirow{2}{*}{$\begin{array}{c}\text { Phosphorus } \\
\left(\mathrm{kg} \mathrm{P}_{2} \mathrm{O}_{5} \mathrm{ha}^{-1}\right)\end{array}$} & With PSB & Without PSB & \multirow{2}{*}{ Mean } \\
\cline { 2 - 3 } & 90.020 & 87.232 & $88.622 \mathrm{c}$ \\
\hline 60 & 91.890 & 90.020 & $90.955 . \mathrm{b}$ \\
\hline 90 & 93.963 & 92.020 & $92.992 \mathrm{a}$ \\
\hline 120 & $91.958 \mathrm{a}$ & $89.754 \mathrm{~b}$ & -------- \\
\hline
\end{tabular}

Values with unlike letters in each row and column are significantly different $(\alpha=0.05)$ from each other LSD ( $\alpha=$ 0.05 ) for $\mathrm{PSB}=0.84, \mathrm{P}=1.03$ and $\mathrm{PSB} \times \mathrm{P}=\mathrm{NS}$

\section{Grain weight}

Result about the effect of P and PSB and their interaction are mentioned in (Table 3). Upon analysis of various result indicated that $\mathrm{P}$, PSB inoculation and their interaction significantly affected 1000 grains weight $(\mathrm{g})$ of wheat. PSB inoculation improved wheat 1000 grain weight over un inoculated treatment. A $120 \mathrm{~kg} \mathrm{P}_{2} \mathrm{O}_{5} \mathrm{ha}^{-1}$ produced 1000 grain (47.91 g) which was appreciably heavier than that of $90 \mathrm{~kg} \mathrm{ha}^{-1}$ whereas, the lighter grains was observed for $60 \mathrm{~kg} \mathrm{ha}^{-1}$. The interaction effect of PSB and $\mathrm{P}$ indicated that $\mathrm{P}$ applied @ 120 kg $\mathrm{P}_{2} \mathrm{O}_{5} \mathrm{ha}^{-1}$ along with PSB produced heaver 1000 grains which was statistically more than the rest of treatment combinations while the lighters grains were noted for $60 \mathrm{~kg} \mathrm{P}_{2} \mathrm{O}_{5} \mathrm{ha}^{-1}$ without PSB produced. $\mathrm{P}$ applied at the rate of $60 \mathrm{~kg} \mathrm{ha}^{-1}$ with PSB produced statistically higher than 1000 grain weight to that of $90 \mathrm{~kg} \mathrm{ha}^{-1} \mathrm{P}$ without PSB and similar to $120 \mathrm{~kg} \mathrm{ha}^{-1} \mathrm{P}$ without PSB. These result demonstrated that PSB inoculation can reduce or may minimize dependence on chemical $\mathrm{P}$ fertilizer up to $100 \%$ under exist soil and climatic conditions and may increase $\mathrm{P}$ use efficiency when applied with phosphatic fertilizers. These findings are in confirmation to those of [19] who reported a significant increase in 1000 grains weight $(46.80 \mathrm{~g})$ over control at that 90 $\mathrm{kg} \mathrm{P}_{2} \mathrm{O}_{5} \mathrm{ha}^{-1}$.

Table 3. Wheat 1000 grains weight as influenced by $P$ application rates and PSB inoculation

\begin{tabular}{|c|c|c|c|}
\hline \multirow{2}{*}{$\begin{array}{c}\text { Phosphorus } \\
\left(\mathbf{k g ~ P}_{\mathbf{2}} \mathbf{O}_{\mathbf{5}} \mathbf{h a}^{-\mathbf{1}}\right)\end{array}$} & With PSB & Without PSB & \multirow{2}{*}{ Mean } \\
\cline { 2 - 3 } & $45.563 \mathrm{c}$ & $42.240 \mathrm{e}$ & $43.902 \mathrm{c}$ \\
\hline 60 & $49.197 \mathrm{~b}$ & $43.430 \mathrm{de}$ & $46.313 \mathrm{~b}$ \\
\hline 90 & $51.213 \mathrm{a}$ & $44.610 \mathrm{~cd}$ & $47.912 \mathrm{a}$ \\
\hline 120 & $48.658 \mathrm{a}$ & $43.427 \mathrm{~b}$ & ------- \\
\hline
\end{tabular}

Values with unlike letters in each row and column are significantly different $(\alpha=0.05)$ from each other LSD ( $\alpha=$ 0.05 ) for $\mathrm{PSB}=0.84, \mathrm{P}=1.03$ and $\mathrm{PSB} \times \mathrm{P}=\mathrm{NS}$

\section{Grain yield ( $\left.\mathrm{kg} \mathrm{ha}^{-1}\right)$}

Result regarding the response of wheat grain yield $\mathrm{P}, \mathrm{PSB}$ and their interaction is presented in (Table 4). Upon analysis of various result indicated that $\mathrm{P}$ and PSB inoculation had significant effect on grain yield while the effect of their interaction was nonsignificant. It was exhibited by the result that PSB inoculation improved wheat yield over un inoculated control treatment. Application 
of phosphorous at the rate of $120 \mathrm{~kg} \mathrm{P}_{2} \mathrm{O}_{5} \mathrm{ha}^{-}$ ${ }^{1}$ produced higher grain yield $\left(2615 \mathrm{~kg} \mathrm{ha}^{-1}\right)$ which was appreciably higher than that of obtained $\left(2541 \mathrm{~kg} \mathrm{ha}^{-1}\right)$ at $90 \mathrm{~kg} \mathrm{ha}^{-1}$ where the lowest yield ( $2347 \mathrm{~kg} \mathrm{ha}^{-1}$ ) was observed for $60 \mathrm{~kg} \mathrm{ha}^{-1}$. The interaction P and PSB was non-significant in this case, however it indicated that $\mathrm{P}$ applied at the rate of $120 \mathrm{~kg}$ $\mathrm{ha}^{-1}$ along with PSB produced relatively higher yield than the rest of treatment combinations. These result also demonstrated that PSB inoculation can reduce or may minimize dependence on chemical $P$ fertilizer up to some extent under exist soil and climatic conditions. According to Khan et al. [10] Wheat grain yield was appreciably improved (by 22\%) from $2920 \mathrm{~kg} \mathrm{ha}^{-1}$ to $3560 \mathrm{~kg} \mathrm{ha}^{-1}$ with application of $90 \mathrm{~kg} \mathrm{P}_{2} \mathrm{O}_{5}$ $\mathrm{ha}^{-1}$ over control.

Table 4. Wheat grain yield in response to $P$ application rates and PSB inoculation

\begin{tabular}{|c|c|c|c|}
\hline \multirow{2}{*}{$\begin{array}{c}\text { Phosphorus } \\
\left(\mathbf{K g ~ P}_{\mathbf{2}} \mathbf{O}_{\mathbf{5}} \mathbf{h a}^{-\mathbf{1}}\right)\end{array}$} & With PSB & Without PSB & \multirow{2}{*}{ Mean } \\
\cline { 2 - 3 } & 2434.3 & 2260.7 & $2347.5 \mathrm{c}$ \\
\hline 60 & 2600.0 & 2482.7 & $2541.3 \mathrm{~b}$ \\
\hline 90 & 2676.7 & 2554.7 & $2615.7 \mathrm{a}$ \\
\hline 120 & $2570.3 \mathrm{a}$ & $2432.7 \mathrm{~b}$ & -------------- \\
\hline
\end{tabular}

Values with unlike letters in each row and column are significantly different $(\alpha=0.05)$ from each other LSD $(\alpha=$ 0.05 ) for $\mathrm{PSB}=45.36, \mathrm{P}=78.57$ and $\mathrm{PSB} \times \mathrm{P}=\mathrm{NS}$

\section{Biological yield}

Result regarding the effect of PSB, $\mathrm{P}$ and their interaction on biological yield is present in (Table 5). Upon analysis of various result indicated that $\mathrm{P}$ and PSB inoculation significantly affected biological yield of wheat while their interaction was observed non-significant. It was exhibited by the result that PSB inoculation improved wheat biological yield over un-inoculated treatment. Phosphorous applied at the rate of $120 \mathrm{~kg} \mathrm{P}_{2} \mathrm{O}_{5} \mathrm{ha}^{-1}$ resulted maximum biological yield of $7129 \mathrm{~kg} \mathrm{ha}^{-1}$ which was statistically similar to that of $90 \mathrm{~kg} \mathrm{P}_{2} \mathrm{O}_{5} \mathrm{ha}^{-1}$ where the lowest was observed for $60 \mathrm{~kg}$ $\mathrm{P}_{2} \mathrm{O}_{5}$ ha $^{-1}$ which was similar to that obtained from plots treated with 90 while lower than that of $120 \mathrm{~kg} \quad \mathrm{P}_{2} \mathrm{O}_{5} \mathrm{ha}^{-1}$. These result demonstrated that PSB inoculation may improve BY of wheat can reduce or may minimize dependence on chemical $P$ fertilizer up to a great extent under exist soil and climatic conditions. The increase in BY may be attributed to the fact that PSB increase nutrient and water use efficiency and $\mathrm{P}$ utilization.

Table 5. Biological yield of wheat as affected by $P$ application rates and PSB inoculation

\begin{tabular}{|c|c|c|c|}
\hline \multirow{2}{*}{$\begin{array}{c}\text { Phosphorus } \\
\left(\mathbf{k g ~ P} \mathbf{P}_{\mathbf{2}} \mathbf{~ h a}^{-\mathbf{1}}\right)\end{array}$} & With PSB & Without PSB & \multirow{2}{*}{ Mean } \\
\cline { 2 - 3 } & 6294.0 & 5898.0 & $6096.0 \mathrm{~b}$ \\
\hline 60 & 6694.3 & 6154.0 & $6424.2 \mathrm{ab}$ \\
\hline 90 & 7896.0 & 6362.0 & $7129.0 \mathrm{a}$ \\
\hline 120 & $6961.4 \mathrm{a}$ & $6138.0 \mathrm{~b}$ & ------------ \\
\hline Mean & &
\end{tabular}

Values with unlike letters in each row and column are statistically different $(\alpha=0.05)$ from each other LSD $(\alpha=0.05)$ for $\mathrm{PSB}=651.03, \mathrm{P}=797$ and $\mathrm{PSB} \times \mathrm{P}=\mathrm{NS}$

\section{Straw yield}

Upon analysis of various result indicated that PSB inoculation had significant effect while
$\mathrm{P}$ rates and $\mathrm{P}^{*} \mathrm{PSB}$ showed non-significant effect on straw yield $\mathrm{kg} \mathrm{ha}^{-1}$ of wheat (Table 6). The PSB inoculation significantly 
enhanced wheat straw yield over un inoculated control treatment. Higher application of $\mathrm{P}\left(120 \mathrm{~kg} \mathrm{ha}^{-1}\right)$ resulted straw yield to $4513 \mathrm{~kg} \mathrm{ha}^{-1}$ whereas the lowest $\left(3748 \mathrm{~kg} \mathrm{ha}^{-1}\right)$ was observed for $60 \mathrm{~kg} \mathrm{ha}^{-1}$. The interaction effect of PSB and P indicated that $\mathrm{P}$ applied at the rate of $120 \mathrm{~kg} \mathrm{ha}^{-1}$ along with PSB produced higher straw yield than the rest of treatment combinations. The increase in straw yield over control in PSB inoculated plots may be due to taller plants. These result demonstrated that PSB inoculation along with $\mathrm{P}$ fertilization may improve straw yield of wheat comparatively better than sole application of $\mathrm{P}$.

Table 6. Straw yield of wheat as affected $P$ application rates and PSB inoculation

\begin{tabular}{|c|c|c|c|}
\hline \multirow{2}{*}{$\begin{array}{c}\text { Phosphorus } \\
\left(\text { Kg P }_{\mathbf{2}} \mathbf{O}_{\mathbf{5}} \mathbf{~ h a}^{-\mathbf{1}}\right)\end{array}$} & With PSB & Without PSB & \multirow{2}{*}{ Mean } \\
\cline { 2 - 3 } & 3859 & 3637 & 3748.5 \\
\hline 90 & 4094 & 3671 & 3882.8 \\
\hline 120 & 5219 & 3807 & 4513.3 \\
\hline Mean & $4391.1 \mathrm{a}$ & $3705.3 \mathrm{~b}$ & ------------ \\
\hline
\end{tabular}

Values with unlike letters in each row and column are significantly different $(\alpha=0.05)$ from each other LSD $(\alpha=$ $0.05)$ for $\mathrm{P}=\mathrm{NS}$ and $\mathrm{PSB} \times \mathrm{P}=\mathrm{NS}$

\section{Wheat phosphorus concentration (\%)}

Analysis of variance exhibited that inoculation and $\mathrm{P}$ application rates significantly affected $\mathrm{P}$ concentration of wheat while non-significant effect was observed in case of their interaction (Table 7). Inoculation significantly improved wheat $\mathrm{P}$ concatenation by $25.3 \%$ over un-inoculated control. Similarly, P concentration was gradually increased with increasing level of P. However, the performance of $120 \mathrm{~kg} \mathrm{P}_{2} \mathrm{O}_{5}$ $\mathrm{ha}^{-1}$ was at par to 90 but significantly better than $60 \mathrm{~kg} \mathrm{P}_{2} \mathrm{O}_{5} \mathrm{ha}^{-1}$. PSB improve $\mathrm{P}$ concentration and uptake by plant by enhancing $\mathrm{P}$ solubalization through soil acidification and organic and mineral acids (nitric and sulphuric acids) production [2022]. Jilani et al. [23] and Yazdani et al. [24] reported that PSB inoculation may reduce $\mathrm{P}$ application as external sources by $50 \%$. Zaida et al. [25] reported significant improvement in $\mathrm{P}$ accessibility for plants through PSB inoculation.

Table 7. Wheat $P$ concentration as affected by interaction of $P$ and PSB

\begin{tabular}{|c|c|c|c|}
\hline Phosphorus & \multicolumn{2}{|c|}{ P concentration (\%) } & \multirow{2}{*}{ Mean } \\
\cline { 2 - 3 }$\left(\mathrm{Kg} \mathrm{P}_{2} \mathrm{O}_{5} \mathrm{ha}^{-1}\right)$ & With PSB & Without PSB & $0.185 \mathrm{~b}$ \\
\hline 60 & 0.211 & 0.161 & $0.206 \mathrm{ab}$ \\
\hline 90 & 0.235 & 0.177 & $0.224 \mathrm{a}$ \\
\hline 120 & 0.241 & 0.185 & ---- \\
\hline Mean & $0.228 \mathrm{a}$ & $0.182 \mathrm{~b}$ & \\
\hline
\end{tabular}

Values with unlike letters in each row and column are significantly different $(\alpha=0.05)$ different from each other. LSD for $\mathrm{P}=0.0272$, PSB 0.0180 , $\mathrm{P} \times \mathrm{PSB}=\mathrm{NS}$

\section{Phosphorus uptake $\left(\mathrm{Kg} \mathrm{ha}^{-1}\right)$}

Results regarding $\mathrm{P}$ uptake by wheat are presented in (Table 8). Both PSB inoculation, $\mathrm{P}$ application and their interaction significantly affected $\mathrm{P}$ uptake in maize. Inoculation with PSB improved P uptake in wheat by $26 \%$ over un-inoculated control. Similarly, P uptake significantly incased with increasing application rate of $\mathrm{P}$. Highest uptake was recorded for plot treated with 120 $\mathrm{Kg} \mathrm{P}_{2} \mathrm{O}_{5} \mathrm{ha}^{-1}\left(22.70 \mathrm{~kg} \mathrm{ha}^{-1}\right)$ followed by 90 $\mathrm{Kg} \mathrm{P}_{2} \mathrm{O}_{5} \mathrm{ha}^{-1}\left(20.34 \mathrm{~kg} \mathrm{ha}^{-1}\right)$ while the lowest 
was observed in plants obtained from plots treated with $60 \mathrm{Kg} \mathrm{P}_{2} \mathrm{O}_{5} \mathrm{ha}^{-1}\left(17.51 \mathrm{~kg} \mathrm{ha}^{-1}\right)$. Interactively, $\mathrm{P}$ uptake increased with increasing $\mathrm{P}$ both in with and without PSB. However, sole application of $120 \mathrm{~kg} \mathrm{P}_{2} \mathrm{O}_{5}$ ha $^{-}$ ${ }^{1}$ resulted comparable uptake as $60 \mathrm{~kg} \mathrm{P}_{2} \mathrm{O}_{5}$ ha $^{-1}$ with PSB treated plots. Furthermore, the performance of $90 \mathrm{~kg} \mathrm{P}_{2} \mathrm{O}_{5} \mathrm{ha}^{-1}$ without PSB was statistically better than $120 \mathrm{~kg} \mathrm{P}_{2} \mathrm{O}_{5} \mathrm{ha}^{-1}$ without PSB.

These findings demonstrated that PSB can increase $\mathrm{P}$ uptake both at lower and higher application of P. Additionally, PSB are capable of reducing the use of by $33 \%$. Similar findings have been observed by several researchers $[23,26]$. This enhancement in soil and plant $P$ availability by PSB could be attributed to production of different organic acids [27] by PSB, which acidify surrounding soils [28] as a result solubilize $\mathrm{P}$ from $\mathrm{Ca}_{3}\left(\mathrm{PO}_{4}\right)_{2}$ in calcareous soils. Similar, converse relationship between $\mathrm{pH}$ and soluble phosphate was also reported previously by Illmer and Schinner [20]. These acids can also relocate adsorbed phosphate through ligand exchange reactions. Organic acids may also act as chelating agent for cations like $\mathrm{Ca}^{2+}, \mathrm{Al}^{3+}$ and $\mathrm{Fe}^{3+}$ and may increase plant $\mathrm{P}$ availability $[22,26,28]$.

Table 8. Wheat $P$ Uptake as affected by interaction of $P$ and PSB

\begin{tabular}{|c|c|c|c|}
\hline \multirow{2}{*}{$\begin{array}{c}\text { Phosphorus } \\
\left(\mathbf{K g ~ P}_{\mathbf{2}} \mathbf{O}_{\mathbf{5}} \mathbf{h a}^{-1}\right)\end{array}$} & \multicolumn{2}{|c|}{ P uptake in $\left(\mathbf{k g ~ h a}^{-\mathbf{1}}\right)$} & \multirow{2}{*}{ Mean } \\
\cline { 2 - 3 } & With PSB & Without PSB & $17.51 \mathrm{c}$ \\
\hline 60 & $20.8 \mathrm{~b}$ & $14.6 \mathrm{e}$ & $20.34 \mathrm{~b}$ \\
\hline 90 & $23.5 \mathrm{a}$ & $17.3 \mathrm{~d}$ & $22.70 \mathrm{a}$ \\
\hline 120 & $24.7 \mathrm{a}$ & $18.6 \mathrm{bc}$ & -------------- \\
\hline Mean & $22.9 \mathrm{a}$ & $17.5 \mathrm{~b}$ & \\
\hline
\end{tabular}

Values with unlike letters in each row and column are significantly different $(\alpha=0.05)$ different from each other. LSD for $\mathrm{P}=1.241, \mathrm{PSB}=1.803, \mathrm{P} \times \mathrm{PSB}=2.111$

\section{Conclusion and recommendations}

Our findings imply that, PSB inoculation and $P$ fertilization and their interaction significantly improved plant height, 1000 grains weight, grain yield and $\mathrm{P}$ uptake in wheat. With increasing rates of $P$ from 60 to $120 \mathrm{~kg} \mathrm{P}_{2} \mathrm{O}_{5} \mathrm{ha}^{-1}$ wheat yield and $\mathrm{P}$ uptake were improved, however this increase was more prominent in inoculated treatments than un-inoculated control. Thus, it can be deduce that PSB inoculation may reduce the use of chemical $\mathrm{P}$ fertilizer up to $45 \mathrm{~kg} \mathrm{ha}^{-1}$ but further studies should be conducted to confirm these results at a variety of soils on other cereals

\section{Authors' contributions}

Conceived and designed the experiments: $\mathrm{M}$ Adnan, S Fahad \& IA Mian, Performed the experiments: A Hussain, Hajira \& F Ullah, Analyzed the data: M Saeed, MW
Muhammad, M Roman, R Perveez \& F Wahid, Contributed materials/ analysis/ tools: F Subhan, MA Raza, M Zamin, F Ullah, KU Rehman \& S Andaleeb, Wrote the paper: M Adnan, A Hussain \& S Iqbal.

\section{References}

1. Adnan M, Shah Z, Arif M, Khan MJ, Mian IA, Sharif M, Alam M, Basir A, Ullah H, Rahman H \& Saleem N (2016). Impact of rhizobial inoculum and inorganic fertilizers on nutrients (NPK) availability and uptake in wheat crop. Can J Soil Sci 96: 169-176.

2. Ortiz-Monasterio JI, Sayre KD, Rajaram S \& McMahom M (1997). Genetic progress in wheat yield and nitrogen use efficiency under four nitrogen rates. Crop Sci 37: 898-904.

3. FAO (2009). Fertilizer yearbook 2009. Rome 
4. Tilman D, Balzer C, Hill J \& Befort BL (2011). Global food demand and the sustainable intensification of agriculture. Proce of the Natio Acad of Sci 108(50), .20260-20264.

5. Malik A (2007). Environmental challenge vis a vis opportunity: the case of water hyacinth. Environ Inter 33(1): 122-138.

6. Brady N (1980). The Nature and Properties of Soils. 8th ed. Macmillan publishers Co., Inc. New York.

7. Bahl GS \& Singh A (1993). Phosphate equilibria in soils in relation to added $\mathrm{P}$, Sesbania aculeate incorporation and cropping a study of solubility relationship. J Ind Soc Soil Sci 41: 233237.

8. Prasad J, Abraham VJ, Minz S, Abraham S, Joseph A, Muliyil JP \& Jacob KS (2006). Rates and factors associated with suicide in Kaniyambadi block, Tamil Nadu, South India, 2000-2002. Inter J of Social Psychiatry 52(1): 65-71.

9. Singh B, Singh Y, Khind CS \& Gupta RK (2002). Optimal phosphorus management in rice wheat system. Better Crops. Curr Sci 16 (1): 12-13.

10. Khan R, Raza A, Gurmani AH, \& Zia MS (2007). Effect of phosphorus application on wheat and rice yield under wheat- rice system. Sarhad J Agric 23(4): 851.

11. Glick BR, Cheng Z, Czarny J \& Duan J (2007). Promotion of plant growth by ACC deaminase-producing soil bacteria. Eur J Plant Pathol 119: 329-339.

12. Zaidi KM \& Ahmad E (2014). Mechanism of phosphate solubilization and physiological functions of phosphate solubilizing microorganisms, In: Phosphate Solubilizing Microorganisms: Principles and application of microphos technology, edited by: Khan, M. S., Zaidi, A., and Musarrat, J., Springer International Publishing Switzerland,
Switzerland, 31 62, doi:10.1007/978-3319-08216-5_2.

13. Rodriguez H \& Fraga R (1999). Phosphate solubilizing bacteria and their role in plant growth promotion. Biotechnol Adv 17: 319-339.

14. Kpomblekou K \& Tabatabai MA (2003): Effect of low-molecular weight organic acids on phosphorus release and phyto availability of phosphorus in phosphate rocks added to soils. Agri Ecosyst Environ 100: 275-284.

15. Basir A, Tahir A, Afridi K, Fahad S, Ahmad Z, Adnan M, Alam M, Shah S, Khan A, Wahid F, Ibrahim M, Rahman IU, Khan MA \& Ali R (2018). Optimization of Sowing Time and Seed Rates Can Enhance Wheat Yield in Semi-arid Environment. Philippine $J$ Agri 101(4): 326- 332.

16. Gyaneshwar P (1999). Involvement of a phosphate starvation inducible glucose dehydrogenase in soil phosphate solubilization by Enterobacterasburiae. FEMS Microbiol Lett 171(2): 223-229.

17. Richards LA (1954). Diagnosis and Improvement of Saline and Alkali soils; Agriculture handbook 60.USDA, US Printing Office, Washington DC.

18. Steel RGD \& Torrie JH (1996). Principles and procedures of Statistics: A Biometrical Approach.- Mc Graw-Hill NY, pp 195-233.

19. Arshad M, Adnan M, Ahmed S, Khan AK, Ali I, Ali M, Ali A, Khan A, Kamal MA, Gul F \& Khan MA (2016). Integrated Effect of Phosphorus and Zinc on Wheat Crop. American-Eurasian $J$ Agric \& Environ Sci 16(3): 455-459.

20. Illmer, P. \& Schinner F (1995). Solubilization of inorganic calcium phosphates-solubilization mechanisms. Soil Biol Biochem 27: 257-263.

21. Chen YP, Rekha PO, Arun AB, Shen FT, Lai WA \& Young CC (2006): Phosphate solublizing bacteria from subtropical 
soils and their tricalcium solublizing abilities, Appl Soil Ecol 34: 33-41.

22. Azam F \& Memon GH (1996). Soil organisms. In: Bashir E, Bantel R (eds) Soil science. National Book Foundation, Islamabad, pp 200-232.

23. Jilani G, Akram A, Ali RM, Hafeez FY, Shamsi IH, Chaudhry AN \& Chaudhry AG (2007). Enhancing crop growth, nutrients availability, economics and beneficial rhizosphere micro flora through organic and bio fertilizers. Annals of Microbiol 57(2): 177-183.

24. Yazdani, M, Bahmanyar MA, Pirdashti H \& Esmaili MA (2009). Effect of phosphate solubilization microorganisms (PSM) and plant growth promoting rhizobacteria (PGPR) on yield and yield components of Corn (Zea maysL.). Proc. World Acad Sci Eng Technol 37:90-92.

25. Zaidi, A., Khan M, Ahemad MS, M O, \& Wani PA (2009). Recent Advances in
Plant Growth Promotion by PhosphateSolubilizing Microbes. In: Khan MS et al (eds) Microbial Strategies for Crop Improvement. Springer-Verlag, Berlin Heidelberg, pp 23-50.

26. Khan A., Jilani A, Akhter G, Naqvi MS, \& Rasheed M (2009): Phosphorus solubilizing Bacteria; occurrence, Mechanisms and their role in crop production, J Agric Biol Sci 1: 48-58.

27. Ryan, J., Estefan G \& Rashid A (2001). Soil and Plant Analysis Laboratory Manual (2nd ed.). Jointly published by the International Center for Agricultural Research in the Dry Areas (ICARDA) and the National Agricultural Research Center (NARC). Available from ICARDA, Aleppo, Syria, pp 172.

28. He, Z. \& Zhu J (1988). Microbial utilization and transformation of phosphate adsorbed by variable charged minerals. Soil Biol Biochem 30: 917-23. 